\title{
Carbonate chemistry of the Dongsha Atoll Lagoon in the northern South China Sea
}

\author{
Lan-Feng Fan ${ }^{1}$, Song-Quan Qiu ${ }^{1}$, and Wen-Chen $\mathrm{Chou}^{1,2, *}$ \\ ${ }^{1}$ Institute of Marine Environment and Ecology, National Taiwan Ocean University, Keelung City, Taiwan \\ ${ }^{2}$ Center of Excellence for the Oceans, National Taiwan Ocean University, Keelung City, Taiwan
}

\section{Article history: \\ Received 29 January 2021 \\ Revised 11 May 2021 \\ Accepted 15 May 2021}

Keywords:

Carbonate chemistry, Dongsha Atoll, Coral reef, $\mathrm{CO}_{2}$, Ocean acidification, South China Sea

\section{Citation:}

Fan, L.-F., S.-Q. Qiu, and W.-C. Chou, 2021: Carbonate chemistry of the Dongsha Atoll Lagoon in the northern South China Sea. Terr. Atmos. Ocean. Sci., 32, 399-409, doi: 10.3319/TAO.2021.05.15.02

\begin{abstract}
In this study, we investigated the seawater carbonate chemistry in the Dongsha Atoll Lagoon (DAL) in summer 2015, summer 2016, and autumn 2016. According to the calculation of the total alkalinity anomaly $(\triangle T A)$, the DAL is currently maintaining a net calcification status, with higher calcification potential in summer and lower calcification potential in autumn. The calculation of the partial pressure of $\mathrm{CO}_{2}$ anomaly $\left(\Delta p \mathrm{CO}_{2}\right)$ shows that the DAL acts as a $\mathrm{CO}_{2}$ source for the atmosphere, with higher $\Delta p \mathrm{CO}_{2}$ values in summer and lower values in autumn. In addition to seasonal variation, $\Delta p \mathrm{CO}_{2}$ also exhibits a clear variation between two summer investigations, with higher values in summer 2016 than in summer 2015, which could be associated with the different weather conditions during the sampling periods (2015 vs. 2016: sunny vs. stormy). Moreover, analyzing the salinity-normalized total alkalinity vs. dissolved inorganic carbon relationship reveals that calcification was the dominant process controlling the $\mathrm{CO}_{2}$ dynamics in summer 2015, while those in summer 2016 were regulated mainly by the combination of calcification and organic respiration. This result further suggests that the change in the organic carbon metabolism induced by the different weather conditions could be the driving force behind the observed variation in $p \mathrm{CO}_{2}$ between summer 2015 and 2016.
\end{abstract}

\section{INTRODUCTION}

The ocean absorbs approximately one-third of the carbon dioxide $\left(\mathrm{CO}_{2}\right)$ that is released into the atmosphere (Sabine et al. 2011). When $\mathrm{CO}_{2}$ is absorbed by seawater, it forms carbonic acid, lowering the $\mathrm{pH}$ and carbonate ion concentration and thereby decreasing the saturation state of seawater with respect to carbonate minerals $(\Omega)$; this process is referred to as "ocean acidification" (Caldeira and Wickett 2005). Many laboratory and mesocosm studies have shown that coral reefs are some of the most sensitive ecosystems to ocean acidification, where calcification is predicted to decrease (Kleypas and Yates 2009) and dissolution is predicted to increase with declining $\mathrm{pH}$ and $\Omega$ (Eyre et al. 2018; Chou et al. 2020).

The carbonate chemistry of coral reef waters has long been known to be modified through organic carbon (photosynthesis and respiration) and inorganic carbon (calcifi-

\footnotetext{
* Corresponding author

E-mail:wcchou@mail.ntou.edu.tw
}

cation and $\mathrm{CaCO}_{3}$ dissolution) metabolism. For example, photosynthesis acts to decrease dissolved inorganic carbon (DIC) concentrations and the partial pressure of $\mathrm{CO}_{2}\left(p \mathrm{CO}_{2}\right)$ and increase $\mathrm{pH}$, whereas the total alkalinity (TA) remains largely unaffected; calcification acts to decrease DIC and TA in a ratio of $1: 2$ and to increase $p \mathrm{CO}_{2}$ but decrease pH (Bates 2002). Previous studies have demonstrated that coral-dominated reef ecosystems are $\mathrm{CO}_{2}$ sources for the surrounding waters (Gattuso et al. 1999), while macroalgadominated reef systems are $\mathrm{CO}_{2}$ sinks (Kraines et al. 1996). These studies indicate that the characteristics of the carbonate chemistry of individual coral reef ecosystems may vary and largely depend on their habitat and community structure (Kleypas et al. 2011). Furthermore, the dependence of organic carbon production and calcium carbonate formation on temperature and light availability suggests that carbonate chemistry in coral reef ecosystems may show substantial temporal variation, e.g., seasonal variation (McNeil et al. 2004; Venti et al. 2014). Consequently, characterizing carbonate chemistry and its variability is critical for better 
predicting the possible effects of ocean acidification on individual coral reef ecosystems.

The Dongsha Atoll is located in the northern South China Sea (SCS, Fig. 1). As a portion of the Coral Triangle, which is the epicenter of coral reef biodiversity, coral reef ecosystems are abundant in the coastal waters of the Dongsha Atoll. Extremely high net ecosystem calcification has been reported in the eastern margin of the Dongsha Atoll (DeCarlo et al. 2017), where the nearshore is shaped by large internal waves (Reid et al. 2019). On the western side of Dongsha Atoll, the coverage of abundant seagrass meadows around Dongsha Island was reported to have important implications for ocean acidification buffering and atmospheric $\mathrm{CO}_{2}$ sequestration (Chou et al. 2018). However, the carbonate chemistry in the Dongsha Atoll lagoon (DAL) has not yet been reported. As it is the largest component of Dongsha Atoll and connects two studied sites that exhibit distinct $\mathrm{CO}_{2}$ dynamics (i.e., on the eastern margin and around Dongsha Island), the carbonate chemistry in the DAL is worthy of further investigation. The present study documents the carbonate chemistry in the DAL for the first time. Our purposes here are to report the observed temporal variations in calcification and sink/source status for atmospheric $\mathrm{CO}_{2}$, examine their controlling processes, and compare our results with those of other studies.

\section{MATERIALS AND METHODS}

\subsection{Study Sites}

The Dongsha Atoll $\left(20.88^{\circ} \mathrm{N}, 116.78^{\circ} \mathrm{E}\right)$ is a massive circular coral reef emerging from a water depth of $\sim 500 \mathrm{~m}$ on the continental slope in the northern SCS (Fig. 1); it is directly in the path of some of the world's largest internal solitary waves (with amplitudes of $100-150 \mathrm{~m}$ ) generated by tidal currents in the Luzon Strait (Hsu and Liu 2000). The living reef flat encircling the lagoon is approximately $46 \mathrm{~km}$ long and $2 \mathrm{~km}$ in width. The diameter of the atoll lagoon is approximately $25 \mathrm{~km}$, and the average water depth is $10 \mathrm{~m}$, with the deepest part being $22 \mathrm{~m}$ deep (Fig. 1). Dongsha Island, located on the western margin of the atoll, is the only part that is higher than sea level. Large seagrass meadows extend from the intertidal to the subtidal zones within the atoll lagoon and around Dongsha Island (Huang et al. 2015). In this study, we investigated the seawater carbonate chemistry throughout the entire DAL in summer 2015 (16 - 18 August), 2016 (22 - 24 August), and autumn 2016 (20 - 21 November). The sampling sites are shown in Fig. 1. There were 24 sites in the interior of the DAL (reef water, R) and 6 - 12 sites in the outer margin of the reef flat. Among the outer margin sites, two sites near the western channels were chosen to serve as the source water end-members (S).

\subsection{Measurements of Water Depth, Temperature, Salinity, and Dissolved Oxygen (DO)}

The water depth, temperature, salinity, and DO at each site were recorded using a multiparameter probe (Ocean Seven 316 Plus CTD; IDRONAUT S.r.l, Italy). The DO sensor was calibrated with a precision of $0.1 \mathrm{mgL}^{-1}(\sim 3.1 \mu \mathrm{M})$ using the water-saturated air method before deployment.

\subsection{Carbonate Chemistry Analysis of Discrete Seawater Samples and Calculation of $p \mathrm{CO}_{2}$}

Discrete seawater samples for TA, DIC, and $\mathrm{pH}$ analyses were taken using a 9-L Nalgene ${ }^{\mathrm{TM}}$ HDPE carboy on site

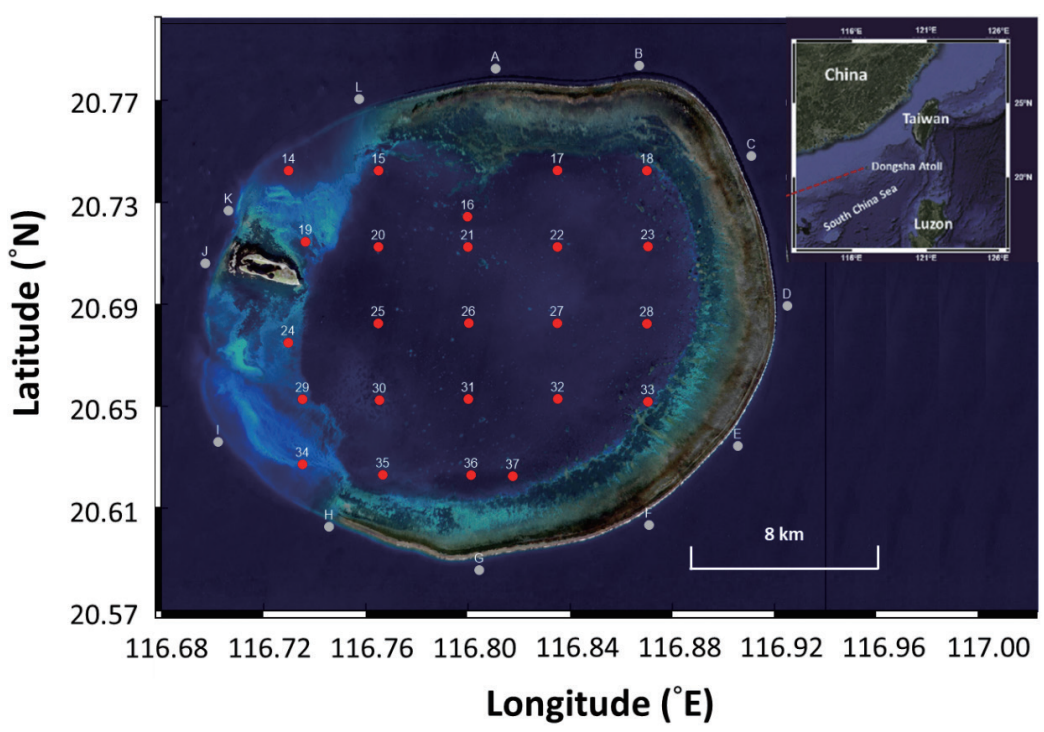

Fig. 1. Locations of sampling sites in the Dongsha Atoll Lagoon, and the inserted map showing the location of the Dongsha Atoll Lagoon in the northern South China Sea. Photo credit: Google Earth Pro V 7.3.3.4507. 
and then immediately transferred into $350-\mathrm{mL}$ precleaned borosilicate bottles. These samples were subsequently injected with $200 \mu \mathrm{L}$ of saturated $\mathrm{HgCl}_{2}$ solution to halt biological activity, sealed, and taken back to the laboratory at National Taiwan Ocean University.

The measurements of TA, DIC, and $\mathrm{pH}$ followed the standard operating methods described in Dickson et al. (2007) and were consistent with those used in our previous studies (Chou et al. 2005, 2018). TA and DIC were measured using Gran titration on an automatic TA titrator (ASALK2, Apollo SciTech Inc.) and the nondispersive infrared method on a DIC analyzer (AS-C3, Apollo SciTech Inc.), respectively. We used certified reference materials (CRMs) obtained from Dr. A. Dickson's laboratory at the Scripps Institution of Oceanography to calibrate and ensure the performance of both the alkalinity titrator and the DIC analyzer. The analytical TA and DIC measurements both had an accuracy and precision of $\pm 0.15 \%$ or better. The $\mathrm{pH}$ was spectrophotometrically determined at $25^{\circ} \mathrm{C}\left(\mathrm{pH}\right.$ at $\left.25^{\circ} \mathrm{C}\right)$ using unpurified meta-cresol purple (mCP) commercially purchased from TCI, which was reported to have the smallest impurity contribution to spectrophotometric characterizations of seawater pH (Clayton and Byrne 1993; Douglas and Byrne 2017). The $\mathrm{pH}$ measurement was based on the total hydrogen ion concentration scale with a precision of 0.005 (Chou et al. 2016).

The seawater $p \mathrm{CO}_{2}$ was calculated from the DIC, TA, temperature, and salinity using the CO2SYS program (Pelletier et al. 2011). The dissociation constants for carbonic acid for this calculation were obtained from the data of Mehrbach et al. (1973) that were refitted by Dickson and Millero (1987), which has been demonstrated to be able to yield the best results when determining $p \mathrm{CO}_{2}$ from DIC and TA (Wanninkhof et al. 1999).

\subsection{Statistical Analysis}

Differences in the means of all parameters among the three sampling seasons, including water temperature, salinity, $\mathrm{DO}, \mathrm{pH}, p \mathrm{CO}_{2}$, DIC, and TA, were assessed using a randomized complete block design (RCBD) to exclude site effects (Montgomery 2012), followed by Tukey's pairwise comparison to determine the significance of differences between each pair of sampling seasons. All statistical analyses were performed with a general linear modeling (GLM) procedure in the SAS 9.4 software package (SAS Institute 2003).

\section{RESULTS}

The variation ranges, means and stand deviations $( \pm 1 \sigma)$ of water temperature, salinity, $\mathrm{DO}, \mathrm{pH}, p \mathrm{CO}_{2}$, DIC, and TA in the DAL in the three sampling periods are summarized in Table 1, and their distributions are shown in Fig. 2.

\subsection{Surface Water Properties of the DAL}

Water temperature in the DAL ranged from 26.9 to $31.2^{\circ} \mathrm{C}$. The water temperature generally decreased from the northeast to the southwest in the lagoon in summer, but no significant spatial variation was found in autumn (Fig. 2a). Salinity in the DAL ranged from 33.2 to 34.1, generally increasing from east to the west in the lagoon in summer and showing no significant pattern in autumn (Fig. 2b).

Both temperature and salinity showed temporal variations in the DAL (Table 1). The temperature in August 2015 was significantly higher than that in August 2016 and higher than that in November 2016 (30.2 \pm 0.6 vs. $29.7 \pm 0.4$ vs. $\left.27.3 \pm 0.3^{\circ} \mathrm{C}, p<0.01\right)$. The salinity in August 2016 was significantly lower than that in August 2015 and lower than that in November $2016(33.6 \pm 0.3$ vs. $33.8 \pm 0.1$ vs. $34.0 \pm$ $0.04, p<0.01)$.

The DO concentration in the DAL ranged from 152 to $236 \mu \mathrm{mol} \mathrm{kg}{ }^{-1}$, with higher levels in the western part of the lagoon in August 2015 and November 2016; the opposite pattern was observed in August 2016 (Fig. 2c). The DO values in August 2015 and November 2016 were not significantly different and were both higher than that in August 2016 (201 \pm 8 vs. $194 \pm 14$ vs. $173 \pm 13 \mu \mathrm{mol} \mathrm{kg}^{-1}, p<0.01$ ).

\subsection{Carbonate Chemistry Parameters in the DAL}

The $\mathrm{pH}$ and $p \mathrm{CO}_{2}$ ranged from 7.838 to 8.103 and 348 to $765 \mu \mathrm{atm}$, respectively. Spatially, the $\mathrm{pH}$ showed higher levels in the western, northern and northeastern parts of the lagoon in August 2015 and 2016 and November 2016, respectively (Fig. 2d). The average $\mathrm{pH}$ in the DAL was generally lower than that in the source water (R vs. S: 8.015 vs. 8.065 in summer $2015,7.974$ vs. 8.089 in summer 2016, and 8.051 vs. 8.069 in autumn 2016, Table 1). $p \mathrm{CO}_{2}$ showed the opposite spatial patterns to $\mathrm{pH}$ (Fig. 2e), and the average $p \mathrm{CO}_{2}$ in the DAL was generally higher than that in the source water (R vs. S: 450 vs. $400 \mu$ atm in summer 2015, 545 vs. $420 \mu$ atm in summer 2016, and 396 vs. $393 \mu$ atm in autumn 2016, Table 1).

DIC and TA ranged from 1796 to $1953 \mu \mathrm{mol} \mathrm{kg}^{-1}$ and 2075 to $2238 \mu \mathrm{mol} \mathrm{kg}^{-1}$, respectively. Spatially, DIC was higher in the southwestern part of the lagoon in summer and in the southeastern part of the lagoon in autumn (Fig. 2f). The average DIC in the DAL was generally lower than that in the source water (R vs. S: 1868 vs. $1905 \mu \mathrm{mol} \mathrm{kg}^{-1}$ in summer 2015, 1887 vs. $1910 \mu \mathrm{mol} \mathrm{kg}^{-1}$ in summer 2016, and 1895 vs. $1926 \mu \mathrm{mol} \mathrm{kg}^{-1}$ in autumn 2016, Table 1). TA was higher in the northwestern and southwestern parts of the lagoon in summer and in the northeastern and southeastern parts of the lagoon in autumn (Fig. 2g). The average TA in the DAL was generally lower than that in the source water (R vs. S: 2151 vs. $2217 \mu \mathrm{mol} \mathrm{kg}{ }^{-1}$ in summer 2015 , 2128 vs. $2215 \mu \mathrm{mol} \mathrm{kg}^{-1}$ in summer 2016, and 2188 vs. 2229 
Table 1. Summary of temperature, salinity, DO, $\mathrm{pH}, p \mathrm{CO}_{2}$, DIC, and TA in the Dongsha Atoll lagoon (the variation range and mean \pm SD for the reef water, $\mathrm{R}$, and only the mean value for the source water, $\mathrm{S}$ ) in different sampling periods: August 2015 (Aug. 2015), August 2016 (Aug. 2016), and November 2016 (Nov. 2016). The significance level ( $p$-value) for the RCBD and the corresponding Tukey's pairwise comparison for all parameter means between each pair of sampling periods are shown.

\begin{tabular}{|c|c|c|c|c|c|c|}
\hline & & August 2015 & August 2016 & November 2016 & $p$-value & Tukey's pairwise comparison \\
\hline \multirow{3}{*}{ Temperature $\left({ }^{\circ} \mathrm{C}\right)$} & $\mathrm{R}$ & $28.5-31.2$ & $29.1-30.3$ & $26.9-27.8$ & $<0.01$ & August $15>$ August $16>$ November 16 \\
\hline & & $30.2 \pm 0.6$ & $29.7 \pm 0.4$ & $27.3 \pm 0.3$ & & \\
\hline & $\mathrm{S}$ & 29.4 & 29.8 & 27.5 & & \\
\hline \multirow{3}{*}{ Salinity } & $\mathrm{R}$ & $33.6-34.0$ & $33.2-34.1$ & $33.9-34.1$ & $<0.01$ & November $16>$ August $15>$ August 16 \\
\hline & & $33.8 \pm 0.1$ & $33.6 \pm 0.3$ & $34.0 \pm 0.04$ & & \\
\hline & $S$ & 33.9 & 33.9 & 34.0 & & \\
\hline \multirow{3}{*}{$\mathrm{DO}\left(\mu \mathrm{mol} \mathrm{kg}{ }^{-1}\right)$} & $\mathrm{R}$ & $184-226$ & $152-195$ & $166-236$ & $<0.01$ & August $15=$ November $16>$ August 16 \\
\hline & & $201 \pm 8$ & $173 \pm 13$ & $194 \pm 14$ & & \\
\hline & $\mathrm{S}$ & 202 & 176 & 183 & & \\
\hline \multirow{3}{*}{$\mathrm{pH}$ at $25^{\circ} \mathrm{C}$} & $\mathrm{R}$ & $7.952-8.103$ & $7.838-8.086$ & $8.025-8.101$ & $<0.01$ & November $16>$ August $15>$ August 16 \\
\hline & & $8.015 \pm 0.040$ & $7.974 \pm 0.063$ & $8.051 \pm 0.021$ & & \\
\hline & $S$ & 8.065 & 8.089 & 8.069 & & \\
\hline \multirow{3}{*}{$p \mathrm{CO}_{2}(\mu \mathrm{atm})$} & $\mathrm{R}$ & $368-514$ & $414-765$ & $348-445$ & $<0.01$ & August $16>$ August $15>$ November 16 \\
\hline & & $450 \pm 42$ & $545 \pm 102$ & $396 \pm 23$ & & \\
\hline & $S$ & 400 & 420 & 393 & & \\
\hline \multirow{3}{*}{$\operatorname{DIC}\left(\mu \mathrm{mol} \mathrm{kg}{ }^{-1}\right)$} & $\mathrm{R}$ & $1796-1916$ & $1816-1985$ & $1866-1953$ & $<0.01$ & November $16>$ August $15^{*}$ \\
\hline & & $1868 \pm 29$ & $1887 \pm 44$ & $1895 \pm 19$ & & \\
\hline & $\mathrm{S}$ & 1905 & 1910 & 1926 & & \\
\hline \multirow{3}{*}{$\mathrm{TA}\left(\mu \mathrm{mol} \mathrm{kg}{ }^{-1}\right)$} & $\mathrm{R}$ & $2084-2238$ & $2075-2220$ & $2153-2238$ & $<0.01$ & November $16>$ August $15=$ August 16 \\
\hline & & $2151 \pm 41$ & $2128 \pm 49$ & $2188 \pm 19$ & & \\
\hline & $S$ & 2217 & 2215 & 2229 & & \\
\hline
\end{tabular}

Note: * The DIC in August 16 was less significantly different from those in August 15 and November 16.

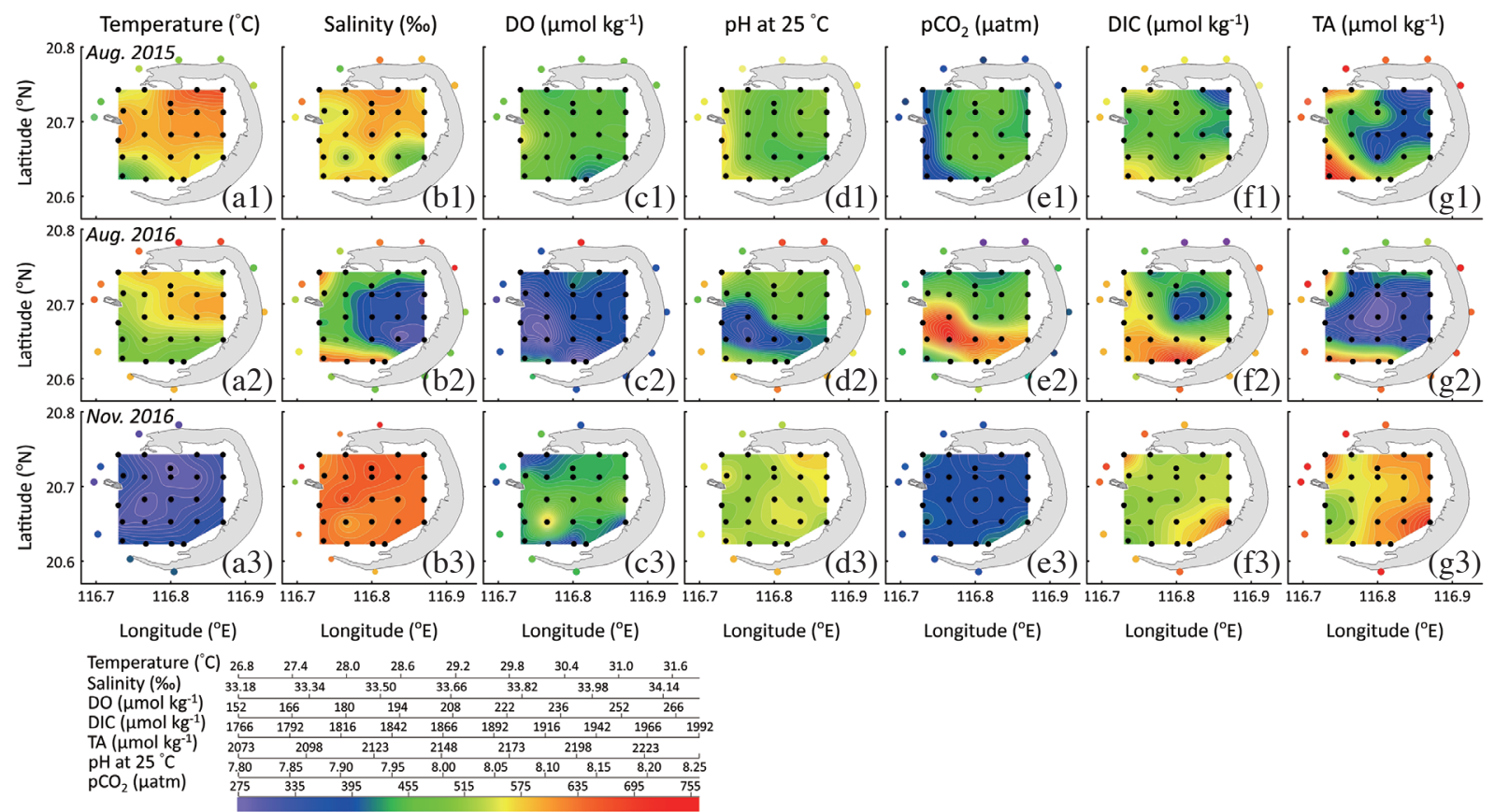

Fig. 2. Surface distributions of (a) temperature, (b) salinity, (c) DO, (d) $\mathrm{pH}$, (e) $p \mathrm{CO}_{2}$, (f) DIC, and (g) TA on the Dongsha Atoll Lagoon in August 2015 and 2016 and November 2016. 
$\mu$ mol $\mathrm{kg}^{-1}$ in autumn 2016, Table 1).

Moreover, all of the carbonate chemistry parameters in the DAL showed temporal variations (Table 1). The $\mathrm{pH}$ in November 2016 was significantly higher, and the $p \mathrm{CO}_{2}$ in November 2016 was significantly lower, than those in August 2015 as well as those in August 2016 (8.051 \pm 0.021 vs. $8.015 \pm 0.040$ vs. $7.974 \pm 0.063, p<0.01 ; 396 \pm 23$ vs. $450 \pm 42$ vs. $545 \pm 102 \mu \mathrm{atm}, p<0.01)$. The DIC in November 2016 was significantly higher than that in August 2015 (1895 \pm 19 vs. $\left.1868 \pm 29 \mu \mathrm{mol} \mathrm{kg}{ }^{-1}, p<0.01\right)$. However, the TA was significantly higher in November 2016 than in August 2015 and 2016 (2188 \pm 19 vs. $2151 \pm 41,2128 \pm$ $\left.49 \mu \mathrm{mol} \mathrm{kg}{ }^{-1}, p<0.01\right)$.

In summary, the observed higher average $\mathrm{pCO}_{2}$ indicates the overall $\mathrm{CO}_{2}$ source status of the DAL. The average TA and DIC were both lower in the interior than in the exterior of the lagoon, suggesting the involvement of inorganic and organic metabolic processes in the lagoon carbonate chemistry. In addition, all the carbonate chemistry parameters showed temporal variations. All these issues will be further examined in the discussion section.

\section{DISCUSSION}

\subsection{The Net Calcification Potential of Coral Reefs in the DAL}

The TA anomaly ( $\triangle \mathrm{TA}$ ) was calculated as the difference between reef TA and source seawater TA values (i.e., reef TA - source water TA), with negative values representing TA depletion and positive values representing TA repletion. $\triangle \mathrm{TA}$ can provide a direct indication of whether a reef is experiencing net calcification (TA depletion) or dissolution (TA repletion) (Cyronak et al. 2018).

According to Cyronak et al. (2018), most of the coral reefs showed extensive depletion of TA relative to the adjacent open ocean (negative $\triangle \mathrm{TA}$ ) for the majority of observations. A similar result was observed in the DAL (Table 2, Fig. 3). As shown in Table 2, the average $\triangle \mathrm{TA}$ within the DAL ranged from -87 to $-41 \mu \mathrm{mol} \mathrm{kg}^{-1}$. This is direct evidence that the reefs on the DAL, on average, are currently in a state of net calcification. Moreover, the calcification potential of the DAL was higher in summer than in autumn according to the average $\Delta \mathrm{TA}$ calculations (-87 and $-66 \mathrm{vs}$. $-41 \mu \mathrm{mol} \mathrm{kg}{ }^{-1}$, Table 2). This result is consistent with the well-established pattern of enhanced summer calcification in tropical corals, mainly as a result of seasonally higher light and temperature conditions (Marshall and Clode 2004; Venti et al. 2014; Vajed Samiei et al. 2015).

It is worth noting that the observed $\triangle \mathrm{TA}$ in the DAL was apparently lower than that on the eastern margin of the Dongsha Atoll, which was reported to be among the highest values worldwide (DeCarlo et al. 2017); the authors suggested that the high calcification rate on the eastern margin of the Dongsha Atoll could be associated with the large in- ternal waves colliding with the atoll and delivering nutrient-rich waters that stimulate rapid metabolism. However, with the present results, it is difficult to determine whether internal waves might be transmitted into the lagoon and subsequently affect calcification in the interior of the DAL. In contrast to the negative $\triangle \mathrm{TA}$ values found on the eastern margin and in the DAL, positive $\triangle \mathrm{TA}$ values were observed in the seagrass meadows around Dongsha Island; these positive values have been suggested to be the result of TA generated through carbonate dissolution and anaerobic processes in the sediments of the seagrass meadows (Chou et al. 2018). The positive $\Delta \mathrm{TA}$ in the seagrass meadows around Dongsha Island may at least partially offset the TA depletion in the DAL from calcification. Consequently, these results in the Dongsha Atoll support the recent hypothesis that seagrass meadows may serve as chemical refugia for the associated coral reefs facing future ocean acidification (Manzello et al. 2012; Unsworth et al. 2012; Camp et al. 2016).

\subsection{The Sink or Source Status of Atmospheric $\mathrm{CO}_{2}$ in the DAL}

To determine the net effect of reef systems on the airsea $\mathrm{CO}_{2}$ exchange, the difference in $p \mathrm{CO}_{2}\left(\Delta p \mathrm{CO}_{2}\right)$ between the reef water $\left(p \mathrm{CO}_{2, \mathrm{R}}\right)$ and the source water $\left(p \mathrm{CO}_{2, \mathrm{O}}\right)$ was defined (Gattuso et al. 1993; Suzuki and Kawahata 2003). A mean $p \mathrm{CO}_{2}$ value of reef water that was higher than that in the source water (i.e., $\Delta p \mathrm{CO}_{2}>0$ ) indicated that the coral reef had the potential to act as a source of atmospheric $\mathrm{CO}_{2}$ as a whole. By contrast, if $\Delta p \mathrm{CO}_{2}<0$, the reef could act as a sink of $\mathrm{CO}_{2}$.

A previous study indicated that the $p \mathrm{CO}_{2}$ values in reef waters were generally higher than those in the source water in most of the Indo-Pacific region (Suzuki and Kawahata 2003), and similar results were observed in the DAL (Table 3, Fig. 3). As shown in Table 3, the average $\Delta p \mathrm{CO}_{2}$ within the DAL showed positive values ranging from 3 to $143 \mu \mathrm{atm}$. This is direct evidence that the reefs on the DAL, on average, are currently acting as a net $\mathrm{CO}_{2}$ source. $\Delta p \mathrm{CO}_{2}$ in the DAL showed seasonal variations, with higher average values in summer and a lower average value in autumn (51 and 143 vs. $3 \mu \mathrm{atm}$, Table 3 ). This seasonal fluctuation pattern, with elevated $p \mathrm{CO}_{2}$ in the warmer, wet season and depressed $p \mathrm{CO}_{2}$ in the cold, dry season, was reported in other oceanic reefs, e.g., reefs in Bermuda and southeastern Florida (Suzuki and Kawahata 2003; Enochs et al. 2019; Lonbørg et al. 2019). It is possible that the observed seasonal fluctuations in $p \mathrm{CO}_{2}$ on reefs resulted from seasonal variations in temperature and the calcification rate (Tables 1 and 2, Fig. 3). Increases in temperature and calcification both increase $p \mathrm{CO}_{2}$, thereby enhancing the release of $\mathrm{CO}_{2}$ to the atmosphere in summertime. In contrast, the decrease in temperature and calcification in autumn drive $p \mathrm{CO}_{2}$ downward .

The high $\triangle p \mathrm{CO}_{2}$ values observed in summer in the 
Table 2. Comparison of the TA anomaly ( $\triangle \mathrm{TA}$, i.e., reef TA - source water TA) and net community calcification (NCC) status in this study and published results from Dongsha Atoll.

\begin{tabular}{|c|c|c|c|c|c|c|c|}
\hline \multirow{2}{*}{ Location } & \multirow{2}{*}{ Site } & \multirow{2}{*}{ Sampling time } & \multicolumn{2}{|c|}{ TA $\left(\mu \mathrm{mol} \mathbf{k g}^{-1}\right)$} & \multirow{2}{*}{$\Delta \mathrm{TA}\left(\mu \mathrm{mol} \mathrm{kg}{ }^{-1}\right)$} & \multirow{2}{*}{ NCC Status } & \multirow{2}{*}{ Reference } \\
\hline & & & Reef water & Source water & & & \\
\hline Eastern Margin & & June 2014 & 2128 & 2241 & -113 & Calcification & DeCarlo et al. 2017 \\
\hline \multirow{2}{*}{ Dongsha Island } & Inner Lagoon & August 2015 & 2810 & 2217 & 593 & Dissolution & \multirow{2}{*}{ Chou et al. 2018} \\
\hline & North Shore & August 2015 & 2244 & 2217 & 27 & Dissolution & \\
\hline \multirow{3}{*}{ Atoll Lagoon } & & August 2015 & 2151 & 2217 & -66 & Calcification & \multirow{3}{*}{ This study } \\
\hline & & August 2016 & 2128 & 2215 & -87 & Calcification & \\
\hline & & November 2016 & 2188 & 2229 & -41 & Calcification & \\
\hline
\end{tabular}

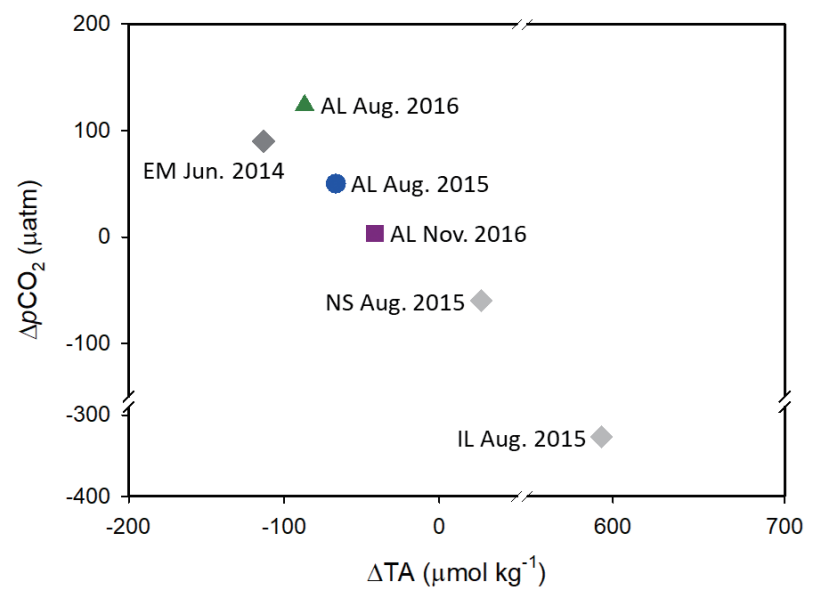

Fig. 3. Plots of the mean $\triangle \mathrm{TA}$ vs. mean $p \mathrm{CO}_{2}$ for the surface water of the Dongsha Atoll system in this study (blue circle, green triangle, and purple square) and previously published results (gray diamond). AL: Atoll lagoon; EM: eastern margin of Dongsha Atoll; IL: inner lagoon of Dongsha Island; NS: north shore of Dongsha Island.

Table 3. Comparison of $\Delta p \mathrm{CO}_{2}$ (i.e., $p \mathrm{CO}_{2}$ of the reef water- $p \mathrm{CO}_{2}$ of the source water) and their sink/source status for atmospheric $\mathrm{CO}_{2}$ in this study and published results from Dongsha Atoll.

\begin{tabular}{|c|c|c|c|c|c|c|c|c|c|c|}
\hline \multirow[b]{2}{*}{ Location } & \multirow[b]{2}{*}{ Site } & \multirow[b]{2}{*}{ Sampling time } & \multicolumn{3}{|c|}{$p \mathrm{CO}_{2}(\mu \mathrm{atm})$} & \multicolumn{2}{|c|}{$\Delta p \mathrm{CO}_{2}(\mu \mathrm{atm})$} & \multicolumn{2}{|c|}{$\mathrm{CO}_{2}$ Status } & \multirow[b]{2}{*}{ Reference } \\
\hline & & & $\begin{array}{c}\text { Reef } \\
\text { water }\end{array}$ & $\begin{array}{c}\text { Source } \\
\text { water }\end{array}$ & Air* & $\begin{array}{c}\text { Reef- } \\
\text { Source }\end{array}$ & Sea-Air & $\begin{array}{c}\text { Reef- } \\
\text { Source }\end{array}$ & Sea-Air & \\
\hline Eastern Margin & & June 2014 & 513 & 423 & 385 & 90 & 128 & Source & Source & DeCarlo et al. 2017 \\
\hline \multirow{2}{*}{ Dongsha Island } & Inner Lagoon & August 2015 & 73 & 400 & 382 & -327 & -309 & Sink & Sink & \multirow{2}{*}{ Chou et al. 2018} \\
\hline & North Shore & August 2015 & 340 & 400 & 382 & -60 & -42 & Sink & Sink & \\
\hline \multirow{3}{*}{ Atoll Lagoon } & & August 2015 & 450 & 400 & 382 & 50 & 68 & Source & Source & \multirow{3}{*}{ This study } \\
\hline & & August 2016 & 545 & 421 & 386 & 124 & 159 & Source & Source & \\
\hline & & November 2016 & 396 & 393 & 390 & 3 & 6 & Source & Sink & \\
\hline
\end{tabular}

Note: * Data from NOAA-ESRL MLO, https://www.co2.earth/, corrected for the saturation vapor pressure of water (Zeebe and Wolf-Gladrow 2001). 
DAL were also found on the eastern margin of the Dongsha Atoll, and both of these values were higher than those reported for most Indo-Pacific coral reefs (Table 1, Suzuki and Kawahata 2003). In coastal reef systems such as the Fanning and Canton Atoll, high $\Delta p \mathrm{CO}_{2}$ values were generally related to terrestrial influences from land (Suzuki and Kawahata 2003; Enochs et al. 2019); however, this is not the case for the DAL. In the Dongsha Atoll system, summer internal waves shoaling from the east regularly transport cold, nutrient-rich water shoreward (Reid et al. 2019), which is likely a key factor explaining the unusually high calcification rate and thus $\Delta p \mathrm{CO}_{2}$ in the eastern margin of the Dongsha Atoll and in the DAL (Table 3, DeCarlo et al. 2017). The effect of internal waves on calcification and $p \mathrm{CO}_{2}$ variation apparently needs more study.

\subsection{Relationships Between $p \mathrm{CO}_{2}$ and DO: The Role of Organic Carbon Metabolism}

In addition to temperature and inorganic calcification, organic carbon metabolism (i.e., photosynthesis and respiration, $\mathrm{P} / \mathrm{R}$ ) may also play a significant role in regulating the $\mathrm{CO}_{2}$ dynamics in the DAL. This role was examined by investigating the relationship between the temperaturecorrected $p \mathrm{CO}_{2}\left(\mathrm{n} p \mathrm{CO}_{2}\right)$ and the apparent oxygen utilization (AOU). AOU is defined as $\mathrm{AOU}=\mathrm{O}_{2 \mathrm{~s}}-\mathrm{O}_{2 \mathrm{~m}}$, where $\mathrm{O}_{2 \mathrm{~m}}$ is the measured $\mathrm{O}_{2}$ concentration and $\mathrm{O}_{2 \mathrm{~s}}$ is its equilib- rium saturation concentration with the in-situ temperature and salinity, calculated using Benson and Krause's formula (1984). A negative AOU indicates that the system tends to be autotrophic, i.e., the production of $\mathrm{O}_{2}$ by photosynthesis is greater than the consumption of $\mathrm{O}_{2}$ by respiration. A positive AOU signifies that the system tends to be heterotrophic, i.e., the consumption of $\mathrm{O}_{2}$ by respiration surpasses the production of $\mathrm{O}_{2}$ by photosynthesis. According to this indicator, the organic carbon metabolism of coral reefs in the DAL varied between two years, i.e., it tended to be autotrophic in August 2015 (average AOU $=-9.4 \mu \mathrm{mol} \mathrm{kg}{ }^{-1}$ ) and heterotrophic in August and November 2016 (20.0 and $7.0 \mu \mathrm{mol} \mathrm{kg} \mathrm{kg}^{-1}$ for August and November, respectively).

To eliminate the effects of temperature on the $p \mathrm{CO}_{2}$ variations, $p \mathrm{CO}_{2}$ was corrected to the average temperature of $29.04^{\circ} \mathrm{C}\left(\mathrm{n} p \mathrm{CO}_{2}\right)$ for the DAL. As shown in Fig. 4, $\mathrm{n} p \mathrm{CO}_{2}$ and $\mathrm{AOU}$ are generally positively correlated, with higher $\mathrm{n} p \mathrm{CO}_{2}$ and a positive AOU in summer 2016 and lower $\mathrm{n} p \mathrm{CO}_{2}$ and a negative AOU in summer 2015. These results suggest that the yearly fluctuations in the summer $p \mathrm{CO}_{2}$ between 2015 and 2016 could be associated with the variations in organic carbon metabolism. We suggest that weather conditions could be one of the possible reasons for these variations (Table 4). Based on the sampling records and weather reports of the Central Weather Bureau, the weather was sunny during the sampling period in summer 2015 but stormy during the sampling period in summer

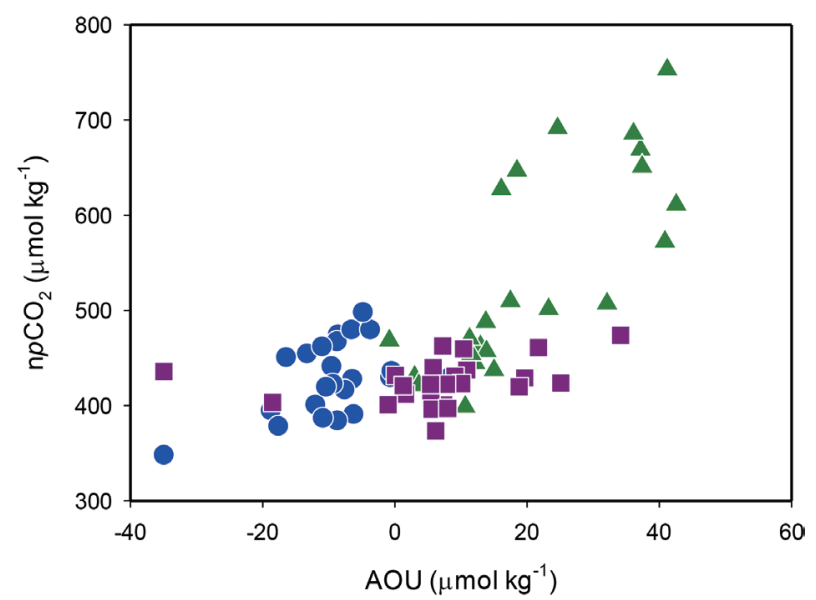

Fig. 4. Plots of temperature-normalized $p \mathrm{CO}_{2}\left(\mathrm{n} \mathrm{CO}_{2}\right)$ vs. apparent oxygen utilization (AOU) in the Dongsha Atoll Lagoon in August 2015 (blue circle), August 2016 (green triangle), and November 2016 (purple square).

Table 4. Summary of wind speed, air temperature, atmosphere pressure, light intensity (the variation range and mean \pm SD for the reef water), and accumulated rainfall in the Dongsha Atoll lagoon during the sampling periods in August (summer) 2015 and 2016.

\begin{tabular}{cccccc}
\hline Sampling period & Wind speed $\left(\mathbf{m ~ s}^{-1}\right)$ & Air temperature $\left({ }^{\circ} \mathbf{C}\right)$ & Atmospheric pressure $(\mathbf{m b r})$ & Light intensity $\left(\mathbf{w} \mathbf{m}^{-2}\right)$ & Accumulated rainfall $(\mathbf{m m})$ \\
\hline \multirow{2}{*}{ August 2015} & $1.22-4.45$ & $29.6-31.3$ & $1007-1010$ & $125-1036$ & $739 \pm 18$ \\
& $3.30 \pm 0.05$ & $30.8 \pm 0.02$ & $1008 \pm 0.1$ & $29-1061$ & 0 \\
\hline \multirow{2}{*}{ August 2016} & $1.27-8.00$ & $25.7-31.0$ & $996-1004$ & $628 \pm 17$ & 30 \\
& $3.82 \pm 0.06$ & $29.5 \pm 0.1$ & $1002 \pm 0.1$ & \multirow{2}{*}{30} \\
\hline
\end{tabular}


2016. The stormy rainfall diluted and caused lower salinity on the DAL (Table 1). The clouds associated with stormy weather may substantially block sunlight and the weaker light intensity was also recorded (Table 4). Weaker light intensity thus diminish photosynthesis, which would lead the DAL to become less autotrophic or more heterotrophic and thereby elevate $p \mathrm{CO}_{2}$. Moreover, it is worth noting that stormy weather could cause a stronger vertical mixing due to stronger wind speed (Table 4), which may transport AOU and $p \mathrm{CO}_{2}$-replete subsurface water into the surface layer, and thus could also partially contribute to the observed higher AOU and $p \mathrm{CO}_{2}$ in August 2016.

\subsection{Relationships Between NTA and NDIC: The Net Effect of Inorganic and Organic Carbon Metabolism on $p \mathrm{CO}_{2}$ Variation}

As discussed previously, both inorganic (calcification $/ \mathrm{CaCO}_{3}$ dissolution, $\mathrm{C} / \mathrm{D}$ ) and organic (photosynthesis/ aerobic respiration, $\mathrm{P} / \mathrm{R}$ ) carbon metabolism may affect seawater $p \mathrm{CO}_{2}$ variation on the Dongsha Atoll. Typically, analyzing the relationship between the salinity-normalized TA and DIC (NTA and NDIC) can provide useful insights into the processes controlling the variations in the $\mathrm{CO}_{2}$ system, as the relative variation in TA and DIC follows a wellestablished stoichiometric relationship that is specific to the respective biogeochemical processes; the ratios for these processes are: $\mathrm{P} / \mathrm{R}=-0.2$ and $\mathrm{C} / \mathrm{D}=2.0$ (Krumins et al. 2013; Sippo et al. 2016). Moreover, a ratio of 0.6 of organic to inorganic carbon metabolism $\left(\mathrm{R}_{\mathrm{OI}}\right.$ ratio) represents the balance level at which the effects of organic and inorganic carbon metabolism on $p \mathrm{CO}_{2}$ variation can offset each other, resulting in a constant $p \mathrm{CO}_{2}$ level (Ware et al. 1992; Suzuki and Kawahata 2003).

Plots of NTA vs. NDIC for the surface water in the DAL are shown in Fig. 5. The baseline for the $\mathrm{R}_{\mathrm{OI}}$ ratio of 0.6 is also superimposed as orange arrows. Generally, the variation in NTA and NDIC in summer 2015 is below the baseline of the $\mathrm{R}_{\mathrm{OI}}$ ratio $=0.6$ and close to the predicted stoichiometric relationship for calcification, indicating the dominance of inorganic carbon metabolism driving DIC and TA variations (Fig. 5a). These conditions may lead to
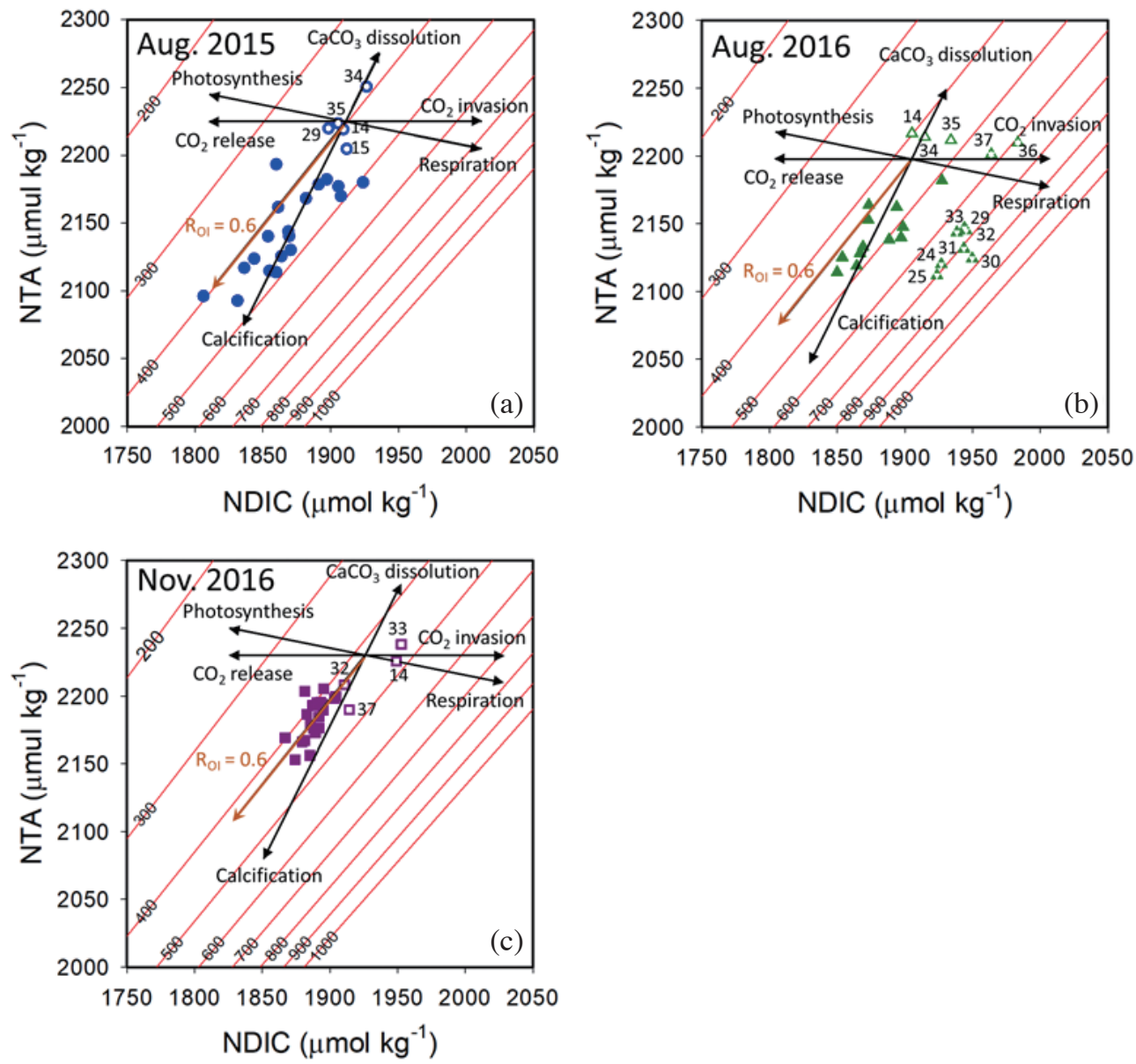

Fig. 5. Plots of NTA vs. NDIC for surface water in August 2015, August 2016, and November 2016 in the Dongsha Atoll Lagoon. Red lines are $p \mathrm{CO}_{2}$ isoline increments. The black arrows show the predicted theoretical variations in TA and DIC caused by various metabolic processes. The orange arrow shows the variations at a constant $\mathrm{R}_{\mathrm{OI}}$ ratio of 0.6 . 
a $p \mathrm{CO}_{2}$ increase. This result is consistent with the tentative conclusion drawn based on the calculation of $\Delta p \mathrm{CO}_{2}$ and $\Delta$ TA (Tables 2 and 3, Fig. 3).

The variation in NTA and NDIC in summer 2016 was also generally below the baseline $\mathrm{R}_{\mathrm{OI}}$ ratio of 0.6 but apparently deviated from the predicted stoichiometric relationship for calcification (Fig. 5b). Figure 5b further reveals that the covariation of NTA and NDIC during summer 2016 could be explained by the combination of calcification and respiration, supported by the observed negative $\triangle \mathrm{TA}$ and positive AOU. The additional DIC released from organic respiration can thus further explain why higher $\Delta p \mathrm{CO}_{2}$ was recorded in summer 2016 than in summer 2015, although the average $\Delta \mathrm{TA}$ was not significantly different between the two years (Fig. 3).

Furthermore, the variation in NTA and NDIC in autumn 2016 is very close to the baseline $R_{\text {OI }}$ ratio $=0.6$ (Fig. $5 \mathrm{c}$ ), indicating that the effects of inorganic and organic carbon metabolism on $\Delta p \mathrm{CO}_{2}$ variation largely offset each other (Gattuso et al. 1993; Kayanne et al. 1995; Frankignoulle et al. 1996). This result is in good agreement with the observed very low $\Delta p \mathrm{CO}_{2}$ in autumn 2016 (Table 3).

\section{CONCLUSIONS}

The present study reports the carbonate chemistry in the DAL for the first time. The observed temporal variations in calcification and the sink/source status of the DAL atmospheric $\mathrm{CO}_{2}$ as well as their controlling processes are summarized in Table 5. First, according to the calculation of $\triangle \mathrm{TA}$, the DAL currently maintains a net calcification status, with higher calcification potential in summer and lower calcification potential in autumn. This result is consistent with the well-established pattern of enhanced summer calcification in tropical coral reefs, which occurs mainly due to seasonally higher light and temperature. Second, the calculation of $\triangle p \mathrm{CO}_{2}$ shows that the DAL acts as a $\mathrm{CO}_{2}$ source for the atmosphere, with higher values in summer and lower values in autumn. This finding is similar to those from other oceanic reefs and primarily reflects the fact that both temperature and calcification are higher in summer. Third, in addition to seasonal variation, $\Delta p \mathrm{CO}_{2}$ also exhibits a clear variation between two summer investigations, with higher values in summer 2016 than in summer 2015. The analysis of the $\mathrm{npCO}_{2}$ vs AOU relationship suggests that the observed variation in summer $p \mathrm{CO}_{2}$ could be associated with a change in the organic carbon metabolic status induced by different weather conditions during the sampling periods in summer 2015 and 2016 (sunny vs. stormy). Finally, the analysis of the NTA vs. NDIC relationship reveals that calcification was the dominant process controlling the $\mathrm{CO}_{2}$ dynamics in summer 2015, while that in summer 2016 was chiefly regulated by the combination of calcification and organic respiration. This result further supports the finding that the change in the organic carbon metabolism could be the driving force behind the variation in $p \mathrm{CO}_{2}$ between summer 2015 and 2016.

Acknowledgements We are grateful to the Dongsha Atoll Research Station, Dongsha Atoll National Park, and the Coast Guard Administration for assistance in field sampling. We thank Rong-Wei Syu, Hui-Chuan Chu, YingHsuan Chen, and Kuan-Chieh Wu for their help with the field and laboratory work.

\section{REFERENCES}

Bates, N. R., 2002: Seasonal variability of the effect of coral reefs on seawater $\mathrm{CO}_{2}$ and air-sea $\mathrm{CO}_{2}$ exchange. Limnol. Oceanogr., 47, 43-52, doi: 10.4319/ lo.2002.47.1.0043. [Link]

Benson, B. B. and D. Krause, 1984: The concentration and isotopic fractionation of oxygen dissolved in freshwater and seawater in equilibrium with the atmosphere. Limnol. Oceanogr., 29, 620-632, doi: 10.4319/ lo.1984.29.3.0620. [Link]

Caldeira, K. and M. E. Wickett, 2005: Ocean model predictions of chemistry changes from carbon dioxide emissions to the atmosphere and ocean. J. Geophys. Res., 110, doi: 10.1029/2004JC002671. [Link]

Camp, E. F., D. J. Suggett, G. Gendron, J. Jompa, C. Manfrino, and D. J. Smith, 2016: Mangrove and seagrass beds provide different biogeochemical services for corals threatened by climate change. Front. Mar. Sci.,

Table 5. Summary of the observed seasonal and two summer cruises variations in calcification and sink/source status of atmospheric $\mathrm{CO}_{2}$ and their controlling factors on the Dongsha Atoll Lagoon.

\begin{tabular}{|c|c|c|c|c|c|c|}
\hline $\begin{array}{l}\text { Sampling } \\
\text { period }\end{array}$ & Weather & $\begin{array}{c}\text { Temperature } \\
\left({ }^{\circ} \mathbf{C}\right)\end{array}$ & $\begin{array}{c}\text { Calcification potential } \\
\left(\Delta \mathrm{TA}, \mu \mathrm{mol} \mathrm{kg}^{-1}\right)\end{array}$ & $\begin{array}{l}\mathrm{CO}_{2} \text { source potential } \\
\left(\Delta \mathrm{pCO}_{2}, \mu \mathrm{\mu tm}\right)\end{array}$ & $\begin{array}{l}\text { Organic metabolism } \\
\left.\text { (AOU, } \mu \mathrm{mol} \mathbf{k g}^{-1}\right)\end{array}$ & $\begin{array}{c}\text { Inorganic vs. organic carbon } \\
\text { dynamics (TA-DIC plot) }\end{array}$ \\
\hline Summer 2015 & Sunny & $\begin{array}{l}\text { Medium } \\
(28.5)\end{array}$ & $\begin{array}{c}\text { Medium } \\
(-66)\end{array}$ & $\begin{array}{c}\text { Medium } \\
(50)\end{array}$ & $\begin{array}{c}\text { Autotrophic } \\
(-9.4) \\
\end{array}$ & $\begin{array}{c}\text { Calcification } \\
\left(\mathrm{R}_{\mathrm{oi}}<0.6\right) \\
\end{array}$ \\
\hline Summer 2016 & Stormy & $\begin{array}{l}\text { High } \\
(29.1)\end{array}$ & $\begin{array}{l}\text { Strong } \\
(-87)\end{array}$ & $\begin{array}{l}\text { Strong } \\
(124)\end{array}$ & $\begin{array}{c}\text { Strongly heterotrophic } \\
\text { (20.0) }\end{array}$ & $\begin{array}{c}\text { Calcification }+ \text { respiration } \\
\left(\mathrm{R}_{\mathrm{oi}}<0.6\right)\end{array}$ \\
\hline Autumn 2016 & Sunny & $\begin{array}{l}\text { Low } \\
(26.9)\end{array}$ & $\begin{array}{l}\text { Weak } \\
(-41)\end{array}$ & $\begin{array}{l}\text { Weak } \\
\text { (3) }\end{array}$ & $\begin{array}{l}\text { Weakly heterotrophic } \\
\text { (7.0) }\end{array}$ & $\begin{array}{l}\text { Balance } \\
\left(\mathrm{R}_{\mathrm{oi}}=0.6\right)\end{array}$ \\
\hline
\end{tabular}


3, 52, doi: 10.3389/fmars.2016.00052. [Link]

Chou, W.-C., D. D.-D. Sheu, C.-T. A. Chen, S.-L. Wang, and C.-M. Tseng, 2005: Seasonal variability of carbon chemistry at the SEATS time-series site, northern South China Sea between 2002 and 2003. Terr. Atmos. Ocean. Sci., 16, 445-465, doi: 10.3319/ TAO.2005.16.2.445(O). [Link]

Chou, W.-C., G.-C. Gong, C.-Y. Yang, and K.-Y. Chuang, 2016: A comparison between field and laboratory $\mathrm{pH}$ measurements for seawater on the East China Sea shelf. Limnol. Oceanogr. Meth., 14, 315-322, doi: 10.1002/ lom3.10091. [Link]

Chou, W.-C., H.-C. Chu, Y.-H. Chen, R.-W. Syu, C.-C. Hung, and K. Soong, 2018: Short-term variability of carbon chemistry in two contrasting seagrass meadows at Dongsha Island: Implications for $\mathrm{pH}$ buffering and $\mathrm{CO}_{2}$ sequestration. Estuar. Coast. Shelf Sci., 210, 3644, doi: 10.1016/j.ecss.2018.06.006. [Link]

Chou, W.-C., P.-J. Liu, Y.-H. Chen, and W.-J. Huang, 2020: Contrasting changes in diel variations of net community calcification support that carbonate dissolution can be more sensitive to ocean acidification than coral calcification. Front. Mar. Sci., 7, 3, doi: 10.3389/ fmars.2020.00003. [Link]

Clayton, T. D. and R. H. Byrne, 1993: Spectrophotometric seawater $\mathrm{pH}$ measurements: Total hydrogen ion concentration scale calibration of m-cresol purple and atsea results. Deep-Sea Res. Part I-Oceanogr.Res. Pap., 40, 2115-2129, doi: 10.1016/0967-0637(93)90048-8. [Link]

Cyronak, T., A. J. Andersson, C. Langdon, R. Albright, N. R. Bates, K. Caldeira, R. Carlton, J. E. Corredor, R. B. Dunbar, I. Enochs, J. Erez, B. D. Eyre, J.-P. Gattuso, D. Gledhill, H. Kayanne, D. I. Kline, D. A. Koweek, C. Lantz, B. Lazar, D. Manzello, A. McMahon, M. Meléndez, H. N. Page, I. R. Santos, K. G. Schulz, E. Shaw, J. Silverman, A. Suzuki, L. Teneva, A. Watanabe, and S. Yamamoto, 2018: Taking the metabolic pulse of the world's coral reefs. PLOS ONE, 13, e0190872, doi: 10.1371/journal.pone.0190872. [Link]

DeCarlo, T. M., A. L. Cohen, G. T. F. Wong, F.-K. Shiah, S. J. Lentz, K. A. Davis, K. E. F. Shamberger, and P. Lohmann, 2017: Community production modulates coral reef $\mathrm{pH}$ and the sensitivity of ecosystem calcification to ocean acidification. J. Geophys. Res., 122, 745-761, doi: 10.1002/2016JC012326. [Link]

Dickson, A. G. and F. J. Millero, 1987: A comparison of the equilibrium constants for the dissociation of carbonic acid in seawater media. Deep-Sea Res. Part I-Oceanogr. Res. Pap., 34, 1733-1743, doi: 10.1016/01980149(87)90021-5. [Link]

Dickson, A. G., C. L. Sabine, and J. R. Christian, 2007: Guide to Best Practices for Ocean $\mathrm{CO}_{2}$ Measurements, PICES Special Publication 3, 191 pp.
Douglas, N. K. and R. H. Byrne, 2017: Achieving accurate spectrophotometric $\mathrm{pH}$ measurements using unpurified meta-cresol purple. Mar. Chem., 190, 66-72, doi: 10.1016/j.marchem.2017.02.004. [Link]

Enochs, I. C., D. P. Manzello, P. R. Jones, S. J. Stamates, and T. P. Carsey, 2019: Seasonal Carbonate chemistry dynamics on southeast Florida coral reefs: Localized acidification hotspots from navigational inlets. Front. Mar. Sci., 6, 160, doi: 10.3389/fmars.2019.00160. [Link]

Eyre, B. D., T. Cyronak, P. Drupp, E. H. De Carlo, J. P. Sachs, and A. J. Andersson, 2018: Coral reefs will transition to net dissolving before end of century. Science, 359, 908-911, doi: 10.1126/science.aao1118. [Link]

Frankignoulle, M., J.-P. Gattuso, R. Biondo, I. Bourge, G. Copin-Montégut, and M. Pichon, 1996: Carbon fluxes in coral reefs. II. Eulerian study of inorganic carbon dynamics and measurement of air-sea $\mathrm{CO}_{2}$ exchanges. Mar. Ecol. Prog. Ser., 145, 123-132, doi: 10.3354/ meps 145123. [Link]

Gattuso, J.-P., M. Pichon, B. Delesalle, and M. Frankignoulle, 1993: Community metabolism and air-sea $\mathrm{CO}_{2}$ fluxes in a coral reef ecosystem (Moorea, French Polynesia). Mar. Ecol. Prog. Ser., 96, 259-267, doi: 10.3354/meps096259. [Link]

Gattuso, J.-P., M. Frankignoulle, and S. V. Smith, 1999: Measurement of community metabolism and significance in the coral reef $\mathrm{CO}_{2}$ source-sink debate. Proc. Natl. Acad. Sci., 96, 13017-13022, doi: 10.1073/ pnas.96.23.13017. [Link]

Hsu, M.-K. and A. K. Liu, 2000: Nonlinear internal waves in the South China Sea. Can. J. Rem. Sens., 26, 72-81, doi: 10.1080/07038992.2000.10874757. [Link]

Huang, Y.-H., C.-L. Lee, C.-Y. Chung, S.-C. Hsiao, and H.J. Lin, 2015: Carbon budgets of multispecies seagrass beds at Dongsha island in the South China sea. Mar. Environ. Res., 106, 92-102, doi: 10.1016/j.marenvres.2015.03.004. [Link]

Kayanne, H., A. Suzuki, and H. Saito, 1995: Diurnal changes in the partial pressure of carbon dioxide in coral reef water. Science, 269, 214-216, doi: 10.1126/science.269.5221.214. [Link]

Kleypas, J. A. and K. K. Yates, 2009: Coral reefs and ocean acidification. Oceanography, 22, 108-117, doi: 10.5670/oceanog.2009.101. [Link]

Kleypas, J. A., K. R. N. Anthony, and J.-P. Gattuso, 2011: Coral reefs modify their seawater carbon chemistry - case study from a barrier reef (Moorea, French Polynesia). Global Change Biol., 17, 3667-3678, doi: 10.1111/j.1365-2486.2011.02530.x. [Link]

Kraines, S., Y. Suzuki, K. Yamada, and H. Komiyama, 1996: Separating biological and physical changes in dissolved oxygen concentration in a coral reef. Limnol. Oceanogr., 41, 1790-1799, doi: 10.4319/ 
1o.1996.41.8.1790. [Link]

Krumins, V., M. Gehlen, S. Arndt, P. Van Cappellen, and P. Regnier, 2013: Dissolved inorganic carbon and alkalinity fluxes from coastal marine sediments: Model estimates for different shelf environments and sensitivity to global change. Biogeosciences, 10, 371-398, doi: 10.5194/bg-10-371-2013. [Link]

Lonbørg, C., M. L. Calleja, K. E. Fabricius, J. N. Smith, and E. P. Achterberg, 2019: The Great Barrier Reef: A source of $\mathrm{CO}_{2}$ to the atmosphere. Mar. Chem., 210, 2433, doi: 10.1016/j.marchem.2019.02.003. [Link]

Manzello, D. P., I. C. Enochs, N. Melo, D. K. Gledhill, and E. M. Johns, 2012: Ocean Acidification Refugia of the Florida Reef Tract. PLOS ONE, 7, e41715, doi: 10.1371/journal.pone.0041715. [Link]

Marshall, A. T. and P. Clode, 2004: Calcification rate and the effect of temperature in a zooxanthellate and an azooxanthellate scleractinian reef coral. Coral Reefs, 23, 218-224, doi: 10.1007/s00338-004-0369-y. [Link]

Mehrbach, C., C. H. Culberson, J. E. Hawley, and R. M. Pytkowicx, 1973: Measurement of the apparent dissociation constants of carbonic acid in seawater at atmospheric pressure. Limnol. Oceanogr., 18, 897-907, doi: 10.4319/lo.1973.18.6.0897. [Link]

McNeil, B. I., R. J. Matear, and D. J. Barnes, 2004: Coral reef calcification and climate change: The effect of ocean warming. Geophys. Res. Lett., 31, L22309, doi: 10.1029/2004GL021541. [Link]

Montgomery, D. C., 2012: Design and Analysis of Experiments, 8th Edition, John Wiley \& Sons, Incorporated, NY, 730 pp.

Pelletier, G. J., E. Lewis, and D. W. R. Wallace, 2011: CO2SYS.XLS: A Calculator for the $\mathrm{CO}_{2}$ System in Seawater for Microsoft Excel/VBA, Version 16, Washington State Department of Ecology, Olympia, Washington.

Reid, E. C., T. M. DeCarlo, A. L. Cohen, G. T. F. Wong, S. J. Lentz, A. Safaie, A. Hall, and K. A. Davis, 2019: Internal waves influence the thermal and nutrient environment on a shallow coral reef. Limnol. Oceanogr., 64, 1949-1965, doi: 10.1002/lno.11162. [Link]

Sabine, C. L., R. A. Feely, R. Wanninkhof, T. Takahashi, S. Khatiwala, and G. Park, 2011: Global oceans [The
Global Ocean Carbon Cycle] in State of the Climate in 2010. Bull. Amer. Meteorol. Soc., 92, S100-S105.

SAS Institute, 2003: SAS User's Guide: Statistics, Release 9.1, SAS Institute, Cary, NC.

Sippo, J. Z., D. T. Maher, D. R. Tait, C. Holloway, and I. R. Santos, 2016: Are mangroves drivers or buffers of coastal acidification? Insights from alkalinity and dissolved inorganic carbon export estimates across a latitudinal transect. Global Biogeochem. Cycles, 30, 753766, doi: 10.1002/2015GB005324. [Link]

Suzuki, A. and H. Kawahata, 2003: Carbon budget of coral reef systems: An overview of observations in fringing reefs, barrier reefs and atolls in the Indo-Pacific regions. Tellus Ser. B-Chem. Phys. Meteorol., 55, 428444, doi: 10.3402/tellusb.v55i2.16761. [Link]

Unsworth, R. K. F., C. J. Collier, G. M. Henderson, and L. J. McKenzie, 2012: Tropical seagrass meadows modify seawater carbon chemistry: Implications for coral reefs impacted by ocean acidification. Environ. Res. Lett., 7, 024026, doi: 10.1088/1748-9326/7/2/024026. [Link]

Vajed Samiei, J., A. Saleh, A. Mehdinia, A. Shirvani, and M. Kayal, 2015: Photosynthetic response of Persian Gulf acroporid corals to summer versus winter temperature deviations. PeerJ, 3, e1062, doi: 10.7717/ peerj.1062. [Link]

Venti, A., A. Andersson, and C. Langdon, 2014: Multiple driving factors explain spatial and temporal variability in coral calcification rates on the Bermuda platform. Coral Reefs, 33, 979-997, doi: 10.1007/s00338-0141191-9. [Link]

Wanninkhof, R., E. Lewis, R. A. Feely, and F. J. Millero, 1999: The optimal carbonate dissociation constants for determining surface water $p \mathrm{CO}_{2}$ from alkalinity and total inorganic carbon. Mar. Chem., 65, 291-301, doi: 10.1016/s0304-4203(99)00021-3. [Link]

Ware, J. R., S. V. Smith, and M. L. Reaka-Kudla, 1992: Coral reefs: Sources or sinks of atmospheric $\mathrm{CO}_{2}$ ? Coral Reefs, 11, 127-130, doi: 10.1007/BF00255465. [Link]

Zeebe, R. E. and D. Wolf-Gladrow, 2001: $\mathrm{CO}_{2}$ in Seawater: Equilibrium, Kinetics, Isotopes, Volume 65, 1st Edition, Elsevier Science, 360 pp. 